7. Економіка підприємства: Навч. -метод. посібник для самостійного вивчення дисциплін / О. Г. Швиданенко та інші - К.: KHEУ, 2000. С.232-240.

8. Економіка підприємства: Структурно-логічний навч. посібник/ За ред. С. Ф. Покропивного. - К.: КНЕУ, 2001. С.145157.

9. Мадзігон В.В. Теорія попиту і пропозиції $\quad$ в $\quad$ підприємницькій $\quad$ діяльності $\quad$ в ринкової економіки на товари і послуги. // Молодь і ринок. - 2011. - №2(73). - С. 41 - 46.

10.Я.О. Орищак М.І. Стебло Основи економіки. м. Тернопіль, 1998p. С - 110.

\title{
References:
}

1. Bondar NM, Makarovskaya TP Business Economics: Textbook. - K .; MAUP, 2003. - 298 p.

2. Bandurka OM, Korobov MI, Orlov PI, Petrova KY Financial activity of the enterprise: Textbook. - K .: Libid, 1998. - 312

3. Belevtsev MI, Shestopalova. Commodity Market Infrastructure: A Textbook. - K., 2005 - 410 p.

4. Birman L. Economics of the firm. Tutorial. M.: M / n Univ. and Management, 2001-104s.

5. Blank IA Trade management. - K .: Ukrainian-Finnish Institute of Management and Business, 1997. - 408 p.

6 .Golubkov EP Marketing researches. Theory and methodology. K .: ASK, 2000. - 221 p.

7. VG Zhmalev, LM Shimanovskaya. Fundamentals of Management and Management. - K .: Ukraine, 2000. - 454 p.

8. Izmailova KV Financial Analysis: Educ. - K .: MAUP, 2001. With 40-42.

9. Z. Kryhovetska, II Tsygylik, and TM Panik. Fundamentals of entrepreneurship. Educ. Manual. - K. 2005. - 239 p.

10. Kardash V.Ya. Commodity Marketing Policy: Educ. - Method. a guide for loneliness. study diss. - K: KNEU, 2000. - 124

11. Sidorenko OI, Redko PS Management: situational exercises: teaching. Toolkit: Situational Learning Dissemination Program - K .: Consortium for Improving Management Education in Ukraine, 2004. - 465 p.

Рецензент д.е.н., професор Ковальська Л.Л.

УДК 005.334:339.137

Дашко I. М. к.е.н., доцент кафедри обліку та менеджменту

Криворізький факультет

Запорізького національного університету

\section{АНТИКРИЗОВЕ УПРАВЛІННЯ В СИСТЕМІ ЗАБЕЗПЕЧЕННЯ КОНКУРЕНТОСПРОМОЖНОСТІ ПІДРИСМСТВА}

Підприємство є цілісна система та складається з взаємозалежних елементів, зв'язків і відносин між ними. Проаналізовано теоретичні підходи щодо антикризового управління в контексті забезпечення конкурентоспроможності. Кризові явища унеможливлюють розвиток підприємницької діяльності підприємства і відповідно його конкурентоспроможність. Відповідно до системоузгодженості елементів підприємства обгрунтовано адаптацію механізму антикризового управління підприємством щодо забезпечення конкурентоспроможності. Поєднання сутнісних елементів антикризового управління та конкурентних позицій підприємств є підгрунтя створення синергетичних ефектів щодо забезпечення конкурентоспроможності в умовах кризових явищ.

Ключові слова: антикризове управління, конкурентоспроможність, ризик, підприємство, моніторинг, діагностика

Dashko I.

\section{ANTI-CRISIS MANAGEMENT IN THE SYSTEM OF ENTERPRISE COMPETITIVENESS}

An enterprise is a holistic system and consists of interdependent elements, relationships and relationships between them. The combination of essential elements of anti-crisis management and the competitive position of enterprises is the basis for creating synergistic effects on ensuring competitiveness in a crisis.Theoretical approaches to crisis management in the context of competitiveness are analyzed. Crisis phenomena make it impossible to develop the enterprise activity of the enterprise and, accordingly, its competitiveness. In accordance with the systematic coherence of the elements of the enterprise, the adaptation of the anti-crisis management mechanism of the enterprise to ensure competitiveness is substantiated.

Keywords: anti-crisis management, competitiveness, risk, enterprise, monitoring, diagnostics

Дашко И. М.

\section{АНТИКРИЗИСНОЕ УПРАВЛЕНИЕ В СИСТЕМЕ ОБЕСПЕЧЕНИЯ КОНКУРЕНТОСПОСОБНОСТИ ПРЕДПРИЯТИЯ}


Предприятие является целостной системой и состоит из взаимосвязанных элементов, связей и отношений между ними. Сочетание сути элементов антикризисного управления и конкурентных позиций предприятий является основой для создания синергетических эффектов по обеспечению конкурентоспособности в условиях кризисных явлений. Проанализированы теоретические подходы к антикризисному управлению в контексте обеспечения конкурентоспособности. Кризисные явления делают невозможным развитие предпринимательской деятельности предприятия и соответственно его конкурентоспособность. Согласно системосогласованности элементов предприятия обоснованно адаптацию механизма антикризисного управления предприятием по обеспечению конкурентоспособности..

Ключевые слова: антикризисное управление, конкурентоспособность, риск, предприятие, мониторинг, диагностика

Постановка проблеми у загальному вигляді i iї зв'язок 3 важливими науковими та практичними завданнями. Кризові явища в економіці виникають періодично. Кризи сучасності $\epsilon$ наслідком прояву локальних управлінських або фінансових помилок. Сучасні економічні реалії ставлять у складне становище всіх учасників світової економіки. В умовах процесів глобалізації, міжрегіональної, міжнародної та міжконтинентальної торгівлі відокремлені кризові явища всередині однієї країни або підприємства $\epsilon$ одним з ланок ланцюга, що приводять до серйозних наслідків в інших країнах, на інших підприємствах, що й спостерігається сьогодні в умовах світової фінансової кризи. Подолання наслідків економічної кризи та її наслідків на будь-якому підприємстві і в будь-якій державі $є$, на сьогоднішній день, актуальне економічне завдання. Вивчення кризових явищ та шляхів виходу з них сьогодні набуває належну значимість. Природно, що кризові явища впливають безпосередньо на конкурентоспроможність підприємств. Управління підприємством в сучасних економічних умовах вимагає від управлінців оволодіння новими знаннями і навичками щодо забезпечення конкурентоспроможності.

Антикризове управління в системі забезпечення конкурентоспроможності підприємства передбачає усвідомлену спробу конструювання майбутнього підставі вивчення факторів невизначеності і урахування різноманітних ризиків.

Теоретичні аспекти антикризового управління в контексті забезпечення конкурентноспроможності, припускають ряд причин, що призводять до кризи. Ці причини прийнято розділяти на зовнішні (не залежні від діяльності підприємства) і внутрішні (залежні від діяльності підприємства). Природно, забезпечення конкурентоспроможності, в умовах кризових явищ, передбачає нейтралізацію кризи, що становить сутність антикризового управління. Своєчасне розпізнавання ознак і природи кризових ситуацій їх локалізація, щодо забезпечення конкурентоспроможності, мають спиратися на аналітичні дослідження щодо моніторингу діяльності підприємства та діагностики.

Таким чином, сучасні науково-практичні дослідження щодо антикризового управління, систем забезпечення конкурентоспроможності мають синергетичний ефект відповідно до вирішення проблематики розвитку підприємств в умовах кризових явищ, зовнішніх, внутрішніх збурень.

Аналіз останніх досліджень, у яких започатковано вирішення проблеми.

Науковою спільнотою сучасності щодо проблематики антикризового розвитку та управління конкурентоспроможністю підприємств проводяться дослідження. Дослідженням антикризового управління присвячені дослідження I.А. Бланка [1, с. 25].

Як правило, усі види ризиків взаємозалежні i впливають на діяльність підприємства. Це ускладнює прийняття рішень щодо оптимізації ризику і вимагає поглибленого аналізу складу конкретних ризиків, причин і факторів їхнього виникнення.

Кризові ситуації передбачають застосування певних методів управління тобто практичного вирішення протиріч при альтернативному розвитку протилежних тенденцій у конкретних обставинах.

Етимологічно слово «управління» походить від дієслова «Управляти», яке означає: a) направляти хід, рух кого-небудь або чого-небудь (Наприклад, керувати 
кораблем, автомобілем);

б) керувати, направляти діяльність, дії кого-небудь або чого-небудь (наприклад, управляти державою, господарством, управляти виробничим процесом). У науці термін «управління» - елемент, функція організованих систем різної природи (біологічних, соціальних, технічних), що забезпечує збереження їх певної структури, підтримання режиму діяльності, реалізацію їх програм і цілей. Існує безліч різних видів управління: стратегічне, оперативне, персональне, державне і т. д.

Антикризове управління необхідно віднести до одного з видів управління. Разом 3 тим, якщо розглядати вищезазначене визначення 3 точки зору підприємства, то антикризове управління не $є$ в строгому сенсі слова управлінням, оскільки в переважній більшості випадків не забезпечує «Збереження структури, підтримку режиму діяльності, реалізацію програм і цілей» підприємства. Наявність діаметрально протилежної цільової спрямованості антикризового управління і власне управління залишає місце для відомих нарікань на адресу антикризового управління. Поява поняття «антикризове управління» в вітчизняній практиці обумовлено введенням правового регулювання діяльності господарюючих суб'єктів, характеризується явищами фінансової неспроможності (Банкрутства). В основі антикризового управління лежать правові акти, назва яких досить точно фіксує специфіку антикризового управління.

Кожне підприємство формує власну антикризову систему, що реалізується на певних рівнях: як інформаційна система про стан і потенційні можливості об'єкта дослідження; як частина системи управління - набір динамічно функціонуючих методик стратегічного аналізу; як структуроутворюючий елемент підприємства. Структура антикризової системи визначається ii функціональним призначенням, особливостями об'єкту дослідження, переліком завдань тощо.

Антикризове управління представлене в [2, с.128] розглядає його, як процес застосування форм, методів і процедур, спрямованих на соціально-економічне оздоровлення фінансово-господарської діяльності індивідуального підприємця, підприємства, галузі, створення й розвиток умов для виходу з кризового стану.

Проведений аналіз дає підстави вважати - антикризове управління більш повно висвітлено в працях О. В. Коваленко. Антикризове управління - це управління, яке спрямовано на передбачення небезпеки кризи, аналіз іiі симптомів і усунення загроз появи кризових ситуацій, а в разі їх появи - аналіз і прийняття швидких заходів ліквідаційного характеру з найменшими втратами та негативними наслідками [4]

Природно, що антикризове управління безпосередньо пов'язане з забезпеченням системи конкурентоспроможністю підприємства. Функціонування підприємства в умовах сучасних економічних реалій припускає можливість виникнення кризових ситуацій. Деякі автори зазначають, що криза або його загроза взагалі невід'ємна частина діяльності підприємства [5, с. 9].

Аналізуючи процес еволюції поняття антикризового управління, можна встановити наступне: антикризове управління займається вивченням системи економічних відносин, які пов'язані з виникненням кризових явищ в процесі функціонування суб'єктів економіки. Історичний характер антикризового управління обумовлений тим, що економічні кризи, які є об'єктом іiі дослідження, мають силу лише на певному щаблі суспільного розвитку. Сама поява антикризового управління стала реакцією на виникнення економічних криз в процесі розвитку капіталістичного способу виробництва.

На увагу заслуговує змістовне дослідження [5], де обгрунтовано поєднується антикризове управління із системою забезпечення конкурентоспроможністю. А.М. Гельвановський визначає конкурентоспроможність як володіння властивостями, що створюють переваги для суб'єкта економічного змагання [5].

Існує певна кількість різних теорій формування й розвитку конкурентоспроможності. Ефективною формою економічного росту $\epsilon$ теорія кластерного механізму М. Портера. Як стверджував М. Портер : «Майже кожна криза 
містить в собі не лише корені невдачі, алей зернята успіху. Сутність управління в умовах кризи як раз і полягає в пошуку та пророщенні цих зернин в ім'я майбутнього врожаю успіху» [6.].

Отже, дослідження проблеми антикризового управління підприємством в системі забезпечення конкурентоспроможністю має велике значення на сучасному етапі динамічного розвитку економіки.

Цілі статті. Метою статті є дослідження ролі антикризового управління в системі забезпечення конкурентоспроможності господарюючого суб'єкту.

Виклад основного матеріалу дослідження 3 повним обгрунтуванням отриманих наукових результатів. В сучасних умовах господарювання, які характеризуються складністю виробничих і управлінських процесів, підвищеною нестабільністю зовнішнього середовища і глобалізацією, важливе місце займає стратегічне управління підприємством. Воно базується на визначенні місії підприємства, обгрунтуванні системи стратегічних цілей та виборі найбільш доцільних напрямів їх досягнення, з метою забезпечення використання потенціалу та конкурентних переваг підприємства. В останні десятиріччя конкурентоспроможність як концепція міцно зайняла лідируючі позиції в економічній науці про зростання та політиці з формування основних чинників, які забезпечують його стабільність.

Особливістю економічних реформ в Україні стала концентрація реформаторських зусиль на мікроекономічному рівні перетворень. Відбувалася спроба скласти конкурентне середовище шляхом штучного створення суб'єктів конкуренції засобами приватизації, демонополізації, розукрупнення підприємств, а також потенційних умов для конкуренції засобами лібералізації цін та торгівлі. Між тим, увага проблемам розбудови спроможності самих підприємств ефективно реагувати на конкурентні виклики практично не приділялася. Засоби макроекономічного регулювання, навпаки, створювали вельми несприятливе середовище для підприємницької активності через жорсткі монетарні обмеження, високий рівень фіскального тиску, заплутаність та непередбачуваність регуляторного середовища. Внаслідок цього спроби налагодження конкурентного середовища в Україні не завдали очікуваного позитивного впливу на економічну динаміку, а посилення конкурентного тиску внаслідок лібералізації імпорту тривалий час не сприяло зміцненню конкурентоспроможності вітчизняних підприємств та національної економіки в цілому. Належну конкурентоспроможність в сучасних умовах набуває країна, в національній економіці якої існує «критична маса» стійких конкурентоспроможних економічних суб'єктів, здатних ефективно будувати свою діяльність у динамічному економічному середовищі, керуючись власними економічними інтересами.

Серед різних видів ситуацій особливе місце займають ситуації невизначеності. Функціонуванню і розвитку багатьох економічних процесів притаманні елементи невизначеності. Це обумовлює появу ситуацій, що не мають однозначного результату (рішення). Якщо існує можливість кількісно і якісно визначати ступінь імовірності того чи іншого варіанта, то це і буде ситуація ризику.

Звідси випливає, що ризикована ситуація пов'язана зі статистичними процесами i їй супроводжують три співіснуючих умови: наявність невизначеності; необхідність вибору альтернативи (при цьому варто мати на увазі, що відмова від вибору також $є$ різновидом вибору); можливість оцінити імовірність здійснення обраних альтернатив.

Слід зазначити, що ситуація ризику якісно відрізняється від ситуації невизначеності. Ситуація невизначеності характеризується тим, що імовірність настання результатів рішень чи подій в принципі невизначена.

Формування різних сценаріїв дозволяє знизити ризики, що породжуються невизначеністю зовнішньої среди. 3 стратегій розвитку визначається сценарій або стратегія розвитку, найкращим чином відповідають умовам, закладеним в них. Залежно від виконання встановлених показників, реалізується один з альтернативних варіантів розвитку, що знаходить відображення в зміні показників інтеграційної системи. На 
підставі статистичних даних, отриманих із зовнішнього середовища i показників, досягнутих організацією, формулюється висновок про необхідність коригування стратегічних сценаріїв і відповідних їм короткострокових стратегій. У тому випадку, якщо фактори зовнішнього середовища змінюються радикальним чином, то і система показників оцінки та управління внутрішнім потенціалом також повинна бути скоригована відповідно до короткострокової і довгострокової стратегії розвитку. У цьому випадку також будуть змінені як оціночні показники, так і їх ідеальні параметри.

Підвищення ефективності діяльності соціально-економічних систем в сучасних умовах можливо не тільки за рахунок вдосконалення іiї організаційно-господарської детальності, сприятливого впливу зовнішніх факторів і застосуванням внутрішніх резервів, але і комплексної оцінки можливих стратегічних перспектив їх подальшого розвитку. У свою чергу оцінювання ефективності діяльності підприємства повинно враховувати не тільки величину накопичених ресурсів, але і ступінь використання потенційних можливостей. Складність формування ефективної системи оцінювання, моніторингу та прогнозування потенціалу соціально-економічної системи для підприємств пов'язана 3 високим розміром витрат на впровадженням сучасних i найбільш поширених систем, створених зарубіжними економістами. Пов'язано це також i 3 проблемою адаптації більшості застосовуваних і зрозумілих в західних країнах фінансових показників, які, в умовах іншої системи бухгалтерського та аналітичного обліку, важкореалізовані. Система збалансованих показників не до кінця зрозуміла підприємцям і складна в застосуванні. У свою чергу, науковці-економісти, пропонуючи системи оцінювання потенціалу підприємства в своїх дослідженнях акцентувались більше на оцінюванні ефективності використання ресурсів, часто не пропонуючи методології адаптації пропонованих механізмів до впровадження у конкретне підприємство з урахуванням його індивідуальних особливостей. Перед менеджментом досить часто постає дилема, яким чином вибудувати систему оцінювання, як виміряти потенціал і яким чином відслідковувати його зміни. Системний підхід оцінювання стійкості, як здатність самої системи повертатися в стан рівноваги при впливі на неї факторів зовнішнього середовища, а також чинити опір процесам деградації i забезпечувати існування умовах стохастичних змін зовнішнього середовища. В такому випадку розуміння сталого зростання соціально - економічних систем можна розуміти 3 одного боку як збереження необхідного рівня стабільності значень заданих показників, a 3 іншого - як формування і підтримка показників, що володіють «приростним» показником в порівнянні з результатами попереднього періоду.

Відновлення економічної стійкості підприємства - одна 3 основних задач, що забезпечують реалізацію головної мети антикризового управління, вимагає найбільших зусиль і витрат ресурсів. Реалізація цього завдання здійснюється шляхом поетапної структурної перебудови всієї економіко-виробничої діяльності підприємства.

Як відомо процес прийняття рішень припускає наявність достатньо повної і правильної інформації. Ця інформація включає проінформованість:

- про наявність і величину попиту на товари і послуги, на капітал;

- про фінансову стійкість і платоспроможність клієнтів, партнерів, конкурентів;

- про ціни, курси, тарифи, дивіденди; про можливості устаткування і нової техніки;

- про позицію, образ дій і можливих рішень конкурентів і ін.

Однак на практиці така інформація часто буває різнорідною, різноякісною, неповною чи перекрученою.

У процесі своєї діяльності підприємці зіштовхуються із сукупністю різних видів ризиків, що відрізняються між собою за місцем і часом виникнення, сукупності зовнішніх і внутрішніх факторів, що впливають на їхній рівень, i, отже за способом їхнього аналізу і методам їхнього опису.

Кризові явища унеможливлюють розвиток підприємницької діяльності підприємства і відповідно його конкурентоспроможність. Конкурентоспроможність повина відповідати фінансово-господарським параметрам навколишнього середовища, 
що є проблематичним в періоли кризи. У глибинних причинах кризи, що суттєво впливають на конкурентноспроможність підприємства, лежать певні фактори. Фактори впливу розподіляються на дві основні групи: зовнішні (не залежать від діяльності підприємства); внутрішні (залежні від діяльності підприємства).

Криза - це крайнє загострення протиріч у соціально-економічній системі (підприємстві, організації), що є загрозою для її існування, нормального функціонування i конкурентоспроможності, небезпека банкрутства i переломний момент в різних процесах» [7].

Зовнішні фактори виникнення кризи рекомендовано класифікувати на: соціальноекономічні фактори загального розвитку країни (зростання інфляції; нестабільність податкової системи; нестабільність регулюючого законодавства; зниження рівня реальних доходів населення; зростання безробіття); ринкові фактори (зниження ємності внутрішнього ринку; посилення монополії на ринку; нестабільність валютного ринку; зростання пропозиції товарів-субститутів); інші зовнішні фактори (політична нестабільність; стихійні лиха; погіршення криміногенної ситуації).

Внутрішні фактори виникнення кризи - це: управлінські (високий рівень комерційного ризику; недостатнє знання кон'юнктури ринку; неефективний фінансовий менеджмент; погане управління витратами виробництва; відсутність гнучкості в управлінні; недостатньо якісна система бухгалтерського обліку та звітності); виробничі (незабезпеченість єдності підприємства як майнового комплексу; застарілі та зношені основні фонди; низька продуктивність праці; високі енерговитрати; перевантаженість об'єктами соціальної сфери та ін.), ринкові (низька конкурентоспроможність продукції; залежність від обмеженого кола постачальників і покупців) [8, с. 21].

Як показують науково-практичні дослідження, найбільший вплив на конкурентоспроможність підприємства надають управлінські чинники [8, с. 29].

Отже, незважаючи на різноманіття чинників, що призводять до проблем у забезпечені конкурентоспроможності на підприємстві, причиною, в більшості випадків, $\epsilon$ недоліки щодо якості управління.

Можна стверджувати, підгрунтям забезпечення конкурентоспроможності в умовах кризових явищ $є$ діагностика і відповідне антикризове управління. [9, с. 20]. Таке управління передбачає ряд етапів які розкривають його сутність і механізм реалізації: досліджується фінансовий стан підприємства [10, с. 233].

Вважаємо за доцільне адаптувати механізм антикризового управління підприємством щодо забезпечення конкурентоспроможності (рис. 1).

Антикризове управління підприємством - це особлива система, що відрізняється комплексним і стратегічним характером та має здатність повністю усувати тимчасові утруднення, зафіксовані в роботі підприємства [11, с. 495].

Доцільно виділити основні принципи, на яких грунтується система антикризового управління - це рання діагностика кризових явищ у фінансовій діяльності підприємства, терміновість реагування на різні кризові явища, адекватність реагування підприємства на ступінь реальної загрози його фінансовому добробуту, а також повна реалізація внутрішнього потенціалу для виходу з кризи [12].

Загалом механізм антикризового управління підприємством щодо забезпечення конкурентоспроможності включає наступні основні блоки: механізм пристосування економіко-виробничих показників підприємства до несприятливого зовнішньоекономічного впливу; механізм мобілізації внутрішніх резервів діяльності підприємства; механізм управління підприємством, що знаходиться в кризовому становищі, з метою забезпечення конкурентоспроможності.

Основна роль в системі антикризового управління підприємства приділяється використанню внутрішніх механізмів стабілізації. Це пов'язано з тим, що успішне застосування цих механізмів дозволяє не тільки зняти фінансовий стрес, а й значною мірою прискорити темпи його економічного розвитку.

Слід зауважити, що протистояння внутрішнім економіко-виробничим збуренням 
забезпечення стійкого розвитку $є$ запорука впровадження конкурентних переваг підприємства.

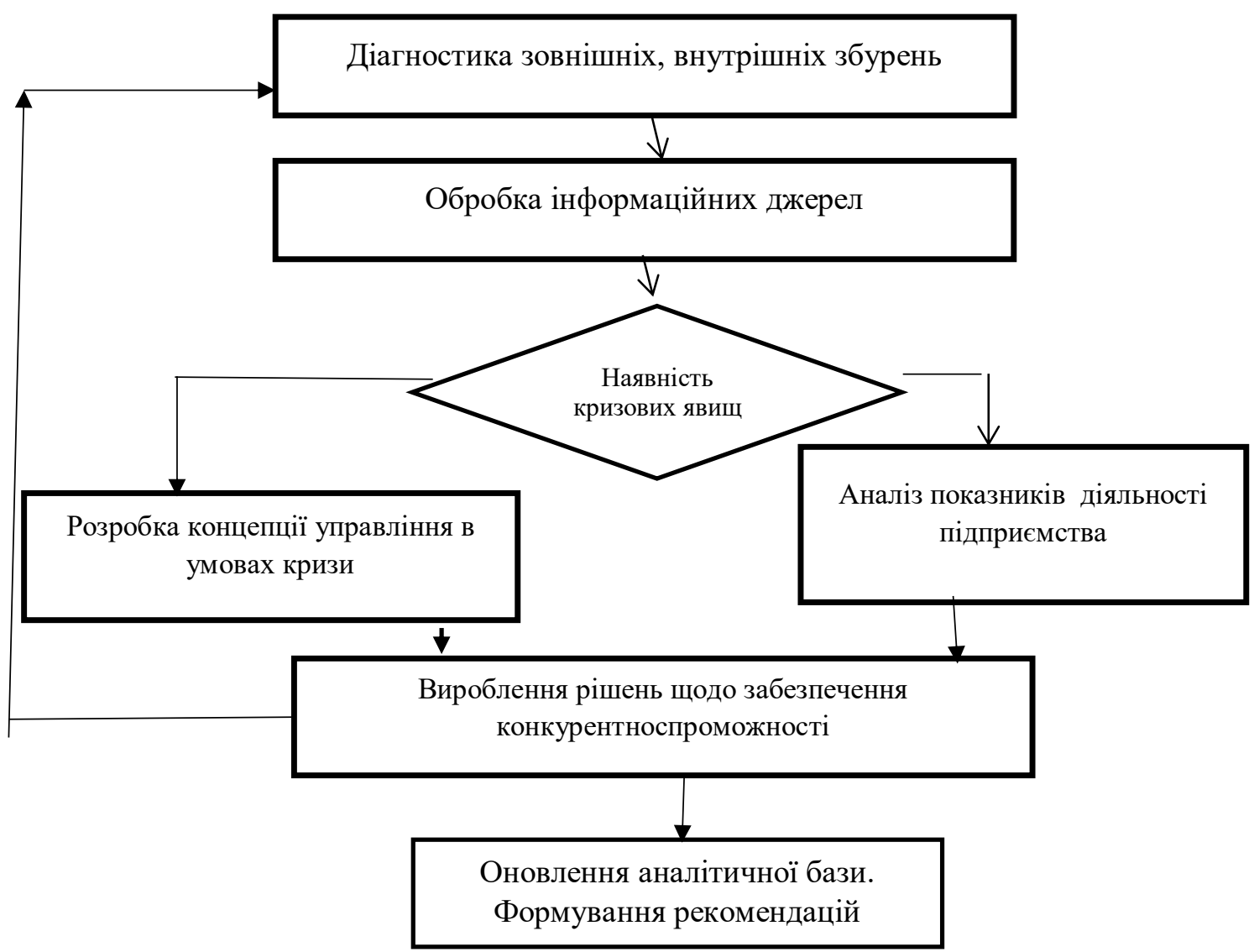

Рис. 1. Схема адаптування механізму антикризового управління підприємством щодо забезпечення конкурентоспроможності

Своєчасне діагностування економічного стану підприємства i прийняття необхідних превентивних заходів щодо запобігання кризи - це завдання реалізується шляхом постійного моніторингу економічного стану підприємства та факторів зовнішнього середовища, що надає найбільш істотний вплив на результати економіковиробничої діяльності. Прийняття превентивних заходів щодо запобігання кризових явищ підприємства $\epsilon$ найбільш економічним напрямом антикризового управління, що забезпечує найбільший ефект (у вигляді зниження майбутніх витрат) на одиницю витрачених в цих цілях фінансових ресурсів $[13,14]$.

Ринкова економіка має велику систему економіко-аналітичних методів діагностики і можливого захисту підприємства від кризи.

Висновки. Проведені дослідження дозволили дійти наступних висновків. Будь-яке підприємство є система і складається з взаємозалежних елементів, зв'язків, відносин і являє собою відповідну цілісність. Відповідно система забезпечення конкурентоспроможності має базуватись на: моніторингу внутрішніх та зовнішніх збурень; проведенні діагностики економіко-виробничих процесів спеціальними методами, притаманними антикризовому управлінню; реалізації заходів та оцінюванні конкурентного статусу підприємства; застосування щодо забезпечення конкурентоспроможності в умовах кризових явищ. Антикризове управління, будучи сукупністю економічних знань, не може не відображати інтереси, що беруть участь в економічній діяльності різних соціальних груп, верств, класів. Це означає, що поряд 3 історичним, має соціальний характер, висловлюючи інтереси провідних соціальних сил 
суспільства. Так, інтереси антикризових керуючих найчастіше приходять в протиріччя 3 інтересами найманих працівників, зайнятих на підприємстві, залучених до процесу реструктуризації або ліквідації. До них додаються інтереси кредиторів, держави, місцевої адміністрації, власника, керівництва підприємства, які, здебільшого, мають різну спрямованість. У зв'язку з цим антикризове управління виявляється ареною боротьби інтересів різних соціальних сил і їх взаємовідносин. Функціональний простір антикризового управління як системи є відображення ії предметної області, що включає елементи, які утворюються на стику взаємодії систем управління різного рівня (працівник, підприємство, муніципальне утворення, область, регіон, держава). Антикризові управлінські впливи формуються по ініціативи безлічі суб'єктів, розподілені серед його носіїв і потребують консолідації, коли існує ймовірність виявлення фінансової неспроможності господарюючого суб'єкта.

Запропоновано адаптацію механізму антикризового управління підприємством щодо забезпечення конкурентоспроможності. Доцільним в подальшому досліджені $є$ розробка стратегічних альтернатив забезпечення конкурентоспроможності підприємств в умовах кризи.

\section{Список бібліографічного опису:}

1.Бланк І.А. Основи фінансового менеджменту [Текст] : навч. посіб. / І.А. Бланк. - К: Ника-Центр, 1999. 489 с.

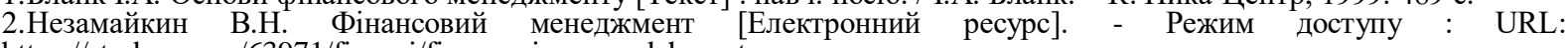
https://stud.com.ua/63971/finansi/finansoviy_menedzhment

3.Антикризове фінансове управління підприємством [Електронний ресурс]. - Режим доступу : URL: http://infopedia.su/11x731d.html - Назва з екрана.

4.Коваленко О. В. Антикризове управління - запорука стабільності роботи підприємства: Вісник Хмельницького національного університету - 2011 - № 2 С.65-68

5.Бірюкова О. Прийоми антикризового менеджменту. К.: Видавничоторгова корпорація «Дашков і К», 2008.430 с. 6.Портер М. Международная конкуренция / М. Портер ; [пер. с англ.]; под. ред. и предисл. В. Д. Щетинина. - М. : Международные отношения, 1993. 896с.

7.Гельвановский М., Жуковская В. Конкурентоспособность в микро, мезо-, макроуровневом измерении. Российский экономический журнал. 1998. № 3 С.234

8.Должанський І., Загорна Т. Конкурентоспроможність підприємства: навч. посіб. К. : Центр навч. л-ри, 2006.384 с 9.Баканов Н.И., Шеремет А.Д. Теория экономического анализа. - М.: Финансы и статистика, 2005. 536 с.

10. Балдін К.В., Бистров О.Ф., Рукосуєв. А.В. Антикризове управління навч. посіб. К.: Дашков і К, 2005. 316 с.

11. Ковалев В. В. Финансовый менеджмент: теория и практика - М.: Проспект. 2007. - 1024 с.

12. Шершньова 3.Є., Багацький В.М., Гетманцева Н.Д. Антикризове управління підприємством навч. посіб. К.: КНЕУ, 2007. $680 \mathrm{c}$.

13. Антикризове vправління підприємством: сутність, етапи здійснення та основні антикризові заходи. - [Електронний pecypc]. - Режим доступу : URL : http://nauka.kushnir.mk.ua/?p=58604. - Назва з екрана.

14. Антикризове фінансове управління підприємством [Електронний ресурс]. - Режим доступу : URL : http://works.doklad.ru/view/4Fv0bk6xVA0/2.html - Назва з екрана.

\section{References}

1.Blank I.A. (1999). Osnovy finansovoho menedzhmentu [Fundamentals of Financial Management]. Nyka-Tsentr, Kyiv, Ukraine

2.Nezamajkyn V.N. ((2017) Finansovyj menedzhment [Financial management]. available at: https://stud.com.ua/63971/finansi/finansoviy menedzhment

3.Crisis financial management of the enterprise. available at http://infopedia.su/11x731d.html -(Accessed 14 Dez. 2019).

4.Kovalenko, O. V. (2011). Antykryzove upravlinnia - zaporuka stabil'nosti roboty pidpryiemstva: [Crisis management is the key to the stability of the enterprise] Visnyk Khmel'nyts'koho natsional'noho universytetu- № 2 pp. 65-68

5.Biriukova, O. (2008). Pryjomy antykryzovoho menedzhmentu. [Techniques of crisis management] Vydavnychotorhova korporatsiia "Dashkov i K. Kyiv, Ukraine

6.Porter, М. (1993). Mezhdunarodnaia konkurentsyia. [International competition] : Международные отношения. Мoskva. Rossyia

7.Hel'vanovskyj, M. and Zhukovskaia, V. (1998)/ Konkurentosposobnost' v mykro, mezo-, makrourovnevom yzmerenyy. [Competitiveness in micro, meso-, macro-level measurement]. Rossyjskyj ekonomycheskyj zhurnal № 3 pp. 234

8.Dolzhans'kyj, I. and Zahorna, T. (2006). Konkurentospromozhnist' pidpryiemstva: navch. posib. [Competitiveness of the enterprise: training. tool.] / Tsentr navch. Kyiv, Ukraine

9.Bakanov N.Y. and Sheremet, A.D. (2005). Peoria ekonomycheskoho analyza. - M.: Fynansy y statystyka [Theory of Economic Analysis]. Fynansy y statystyka. Moskva. Rossyia

10. Baldin K.V., Bystrov, O.F. and Rukosuiev,. A.V. (2005). Antykryzove upravlinnia navch. posib. [Crisis management training tool] Dashkov i K.: Kyiv, Ukraine

11. Kovalev V.V. (2007). Fynansovyj menedzhment; teoryia y praktyka-[Financial management; theory and practice] Prospekt, Moskva. Rossyia

12. Shershn'ova Z.Ye., Bahats'kyj V.M. and Hetmantseva N.D. (2007). Antykryzove upravlinnia pidpryiemstvom navch. posib. [ Crisis Management Enterprise Training tool]. KNEU. Kyiv, Ukraine

13. Enterprise crisis management: essence, stages of implementation and basic anti-crisis measures. Available at http://nauka.kushnir.mk.ua/?p=58604.-(Accessed 14 Dez. 2019).

14. Anti-crisis financial management of enterprises. Available at: http://works.doklad.ru/view/4Fv0bk6xVA0/2.html (Accessed 24 Dez. 2019).

Рецензент д.т.н., професор Кудінов В.В. 